passing under the Cambrian conglomerates, such evidence would go a great way. I have examined some spots where the Cambrian conglomerate has left cakes sitting on the gneiss, and at these spots I should say decidedly that there was no proof of the glaciation of the subjacent rock.

That there may be such evidence at other points is very possible ; and if Mr. Geikie can establish it he will have made a discovery of high interest in geology.

August 27

\section{New Red Star}

Mr. ORmond Stone, writing from Mount Lookout, U.S., Iately informed me that on August 6 he found a very red star, $6.5 \mathrm{mag}$. in rgh. rom. \pm , and $-16^{\circ} 7^{\prime} \pm$. I observed it last night, when it appeared, according to my estimation, of no more than 7.5-8 magnitude. In colour it ranks among the most remarkable red stars, and as it is also, very probably, a variable, I would recommend it to the close attention of observers. It agrees approximately in R.A. with the well-known variable T Sagittarii, but differs in more than a clegree of declination from that star, of which I find the place in wy Red Star Catalogue to be $\alpha, \mathrm{Igh}, 9 \mathrm{~m}, \mathrm{r} 9 \mathrm{~s}$, ; and $\delta,-17^{\circ} 10^{\prime} \cdot 7$ for 1880 . In about that position last night $I$ found a small colourless star not more than ro or XI magnitude.

Millbrook, Tuam, August 29

\section{Locusts and Coffee Trees}

MR. S. B. O'LEARY of this city has favoured me with extracts from a letter written by a relation of his residing on a plantation near Antioua-Guatemala, and containing information about the locust-plague, by which lately the crops of Indian corn and a great many coffee-plantations in that country have been destroyed. The insect is called Chapulin (Gryllus miles, Drury?), and appeared first in the department of Chiquimula, in the eastern part of Guatemala, close to Honduras. Thence it spread over all the warmer parts of the Republic, avoiding the higher and cooler regions. The loss must be very considerable; one gentleman, Don Gregorio Revuelto, in the department of Suchitepeque, lost in one night 70,000 trees, without there being left one single leaf. In April a swarm, supposed to be four leagues broad and about 300 metres long, approached the estate belonging to the writer of the letter, but fortunately could be partly driven away with noise and smoke.

These facts are interesting, as it has not been observed hitherto that locusts, in such a degree, attack the coftee-tree.

Carícas, Angust 2

A. ERNS'T

\section{Intellect in Brutes}

A VERY interesting instance of animal intelligence has been recently reported in one of our newspapers, and may appear sufficiently remarkable to merit more extended notice. A large and destructive fire lately took place upon the shores of the East River opposite to New York, between which city and Long Island this channel passes. The occasion was the spread of naphtha from a burning oil-ship, which instantly became a trail of fire from which the flames swept into well-filled lumber-yards covered with pine boards, and thence to the loaded barges which lined the docks along the river front, and extended up the banks of a small neighbouring creek.

By the rapid and uncontrolled advance of the conflagration over this wide area the families and occupants of the barges and in the lumber-yards were driven away and forced to seek safety in flight. A Newfoundland dog belonging to the grounds, and at that time roaming amongst the lanes of lumber, found himself imprisoned by a swiftly-contracting arc of flame, with the river on one side as the single avenue of escape. Unlike the beasts in the notable dilemma of Baron Munchausen, these opposed elements refused to leap over the back of their prey, and, extinguishing each other, permit him to escape.

The dog jumped into the water and headed for the opposite (the New York) shore. Although pursued by men in boats and lured by cries and calls from the shores, he steadily kept on his course, and after a long and difficult trip landed on the New York side of the water. From the shore he reached one of the avenues which run lengthwise through New York, and finally found his way to the $34^{\text {th }}$ Street ferry, which lay at a consider. able distance below the point of his landing. The dog, following the lumber-waggons, had often crossed from one shore to the other by means of this ferry, and now recognised in his present extremity, he easily secured a single passage.

Once returned to the Long Island side, he regained his old quarters, having by this circuitous ronte baffled the fire and regained his home.

Amer. Mus, Nat. Hist., N.Y., August I4

Chatel, Jersey, must send a more precise address.

\section{THUNDERSTORMS ${ }^{1}$}

III.

THE name thunderbolt, which is still in use, even by good writers, seems to have been introduced in consequence of the singular effects produced when lightning strikes a sandhill or sandy soil. It bores a hole often many feet in length, which is found lined throughout with vitrified sand. The old notion was that an intensely hot, solid mass, whose path was the flash of lightning, had buried itself out of sight, melting the sand as it went down. It is quite possible that this notion may have been strengthened by the occasional observation of the fall of aerolites, which are sometimes found, in the holes they have made, still exceedingly hot. And at least many of the cases in which lightning is said to have been seen in a perfectly clear sky are to be explained in the same way. Every one knows Horace's lines-

$$
\begin{aligned}
& \text { " } \text { 'Diespiter } \\
& \text { Igni corusco nubila dividens } \\
& \text { Plerumque, per purum tonantes } \\
& \text { Egit equos volucremque currum." }
\end{aligned}
$$

But Virgil's remark is not so commonly known. He is speaking of prodigies of various kinds, and goes on :-

" Non alias coelo ceciderunt plura sereno,

FuIgura ; nec diri toties arsere cometae."

It is very singular that he should thus have associated comets and meteorites, which quite recent astronomical discovery has shown to have a common origin.

Another remarkable peculiarity, long ago observed, is the characteristic smell produced when lightning strikes a building or a ship. In old times it was supposed to be sulphurous; nowadays we know it to be mainly due to ozone. In fact, all the ready modes of forming ozone which are as yet at the disposal of the chemist depend upon applications of electricity. But besides ozone, which is formed from the oxygen of the air, there are often produced nitric acid, ammonia, and other compounds derived from the constituents of air and of aqueous vapour. All these results can be produced on a small scale in the laboratory.

Hitherto I have been speaking of lightning discharges similar in kind to the ordinary electric spark, what is commonly called forked or zig-zag lightning. Our nomenclature is very defective in this matter, and the same may be said of the chief modern European languages. For, as Arago remarks, by far the most common form of lightning flash obscrved in thunderstorms is what we have to particularise, for want of a better term, as sheetlightning. He asserts that it occurs thousand-fold as often as forked lightning; and that many people have never observed the latter form at all! It is not at all easy to conceive what can be the nature of sheet-lightning, if it be not mercly the lighting up of the clouds by a flash of forked lightning not directly visible to the spectator. That this is, at least in many cases, its origin is evident from the fact that its place of maximum brightness often takes the form of the edge of a cloud, and that the same cloudedge is occasionally lit up several times in quick succes-

I Abstract of a lecture, delivere $\mathrm{A}$ in the Ciiy Hall, Glasgow, by Prof. Tait. Continued from p. $3^{65}$. 
sion. You will remember that we are at present dealing with the appearances observed in a thunderstorm, so that I do not refer to that form of sheet-lightning which commonly goes by the name of summer-lightning, and which is not, audibly at least, followed by thunder.

The next remarkable feature of the storm is the thunder, corresponding, of course, on the large scale, to the snap of an electric spark. Here we are on comparatively sure ground, for sound is very much more thoroughly understood than is electricity. We speak habitually and without exaggeration of the crash of thunder, the rolling of thunder, and of a peal of thunder; and various other terms will suggest themselves to you as being aptly employed in different cases. All of these are easily explained by known properties of sound. The origin of the sound is in all cases to be looked for in the instantaneous and violent dilatation of the air along the track of the lightning flash, partly, no doubt, due to the disruptive effects of electricity of which I have already spoken, but mainly due to the excessive rise of temperature which renders the air for a moment so brilliantly incandescent. There is thus an extremely sudden compression of the air all round the track of the spark, and a less sudden, but still rapid, rush of the air into the partial vacuum which it produces. Thus the sound-wave produced must at first be of the nature of a bore or breaker. But as such a state of motion is unstable, after proceeding a moderate distance the sound becomes analogous to other loud but less violent sounds, such as those of the discharge of guns. Were there few clouds, were the air of nearly uniform density, and the flash a short one, this would completely describe the phenomenon, and we should have a thunder crash or thunder clap according to the greater or less proximity of the seat of discharge. But, as has long been well known, not merely clouds but surfaces of separation of masses of air of different density, such as constantly occur in thunderstorms, reflect vibrations in the air ; and thus we may have many successive echoes, prolonging the original sound. But there is another cause, often more efficient than these. When the flash is a long one, all its parts being nearly equidistant from the observer, he hears the sound from all these parts simultaneously ; but if its parts be at very different distances from him, he hears successively the sounds from portions farther and farther distant from him. If the flash be much zig-zagged, long portions of its course may run at one and the same distance from him, and the sounds from these arrive simultaneously at his ear. Thus we bave no difficulty in accounting for the rolling and pealing of thunder. It is, in fact, a mere consequence, sometimes of the reflection of sound, sometimes of the finite velocity with which it is propagated. The usual rough estimate of five seconds to a mile is near enough to the truth for all ordinary calculations of the distance of a flash from the observer.

The extreme distance at which thunder is heard is not great, when we consider the frequent great intensity of the sound. No trustworthy observation gives in general more than about nine or ten miles, though there are cases in which it is possible that it may have been heard fourteen miles off. But the discharge of a single cannon is often heard at fifty miles, and the noise of a siege or naval engagement has certainly been heard at a distance of much more than Ioo miles. There are two reasons for this: the first depends upon the extreme suddenness of the production of thunder; the second, and perhaps the more effective, on the excessive variations of density in the atmosphere, which are invariably associated with a thunderstorm. In certain cases thunder has been propagated, for moderate distances from its apparent source, with a velocity far exceeding that of ordinary sounds. This used to be attributed to the extreme suddenness of its production; but it is not easy, if we adopt this hypothesis, to see why it should not occur in all cases. Sir W. Thomson has supplied a very different explanation, which requires no unusual velocity of sound, because it asserts the production of the sound simultaneously at all parts of the air between the ground and the cloud from which the lightning is discharged.

We now come to an exceedingly strange and somewhat rare phenomenon, to which the name of fire-ball or globelightning has been given. As we are as yet unable to produce anything of this kind by means of our electrical machines, some philosophers have tried to cut the Gordian knot of the difficulty by denying that any such thing can exist. But, as Arago says, "Oit en serions nous, si nous nous mettions à nier tout ce qu'on ne sait pas expliquer?" The amount of trustworthy and independent evidence which we possess as to the occurrence of this phenomenon is such as must convince every reasonable man who chooses to pay due attention to the subject. No doubt there is a great deal of exaggeration, as well as much imperfect and even erroneous observation, in almost all of these records. But the existence of the main feature (the fire-ball) seems to be proved beyond all doubt.

The most marked peculiarities of this species of lightning-discharge are its comparatively long duration and its comparatively slow motion. While a spark, or lightning-flash, does not last longer than about a millionth part of a second, if so long, globe-lightning lasts from one to ten seconds, sometimes even longer, so that a sufficiently self-possessed spectator has time carefully to watch its behaviour. The general appearance is that of a luminous ball, which must be approximately spherical, because it always appears circular in outline, slowly and steadily descending from a thundercloud to the ground. It bursts with a loud explosion, sometimes before reaching the ground, sometimes as it impinges, and sometimes after actually rebounding. Its size varies from that of a child's head to a sphere of little less than a yard in diameter. On some occasions veritable flashes of lightning were seen to proceed from large fire-balls as they burst. It is difficult to imagine what these balls can be if they be not a species of natural Leyden jar very highly charged. If it be so, no ordinary lightning-rod can possibly prevent danger from it ; and we may thus be able to explain the very few cases in which damage has been done by lightning to thoroughly protected buildings. To guard against this form nothing short of a pretty close net-work of stout copper wires would suffice. Meanwhile I give a brief sketch of two out of the long series of descriptions of such phenomena which Arago has.patiently collected. The first is given on the authority of Babinet, who was deputed by the Academy of Sciences to make inquiries into the case.

Shortly, but not immediately, after a loud ppeal of thunder, a tailor who was sitting at his dinner saw the paper ornament which covered his fire-place blown down as if by a gentle breeze, and a globe of fire, about the size of a child's head, came gently out and moved slowly about at a slight elevation above the floor. It appeared bright rather than hot, and he felt no sensation of warmth. It approached him like a little kitten which desired to rub itself in play against his legs; but he drew his feet away, and by slow and cautious movements avoided contact with it. It remained several seconds near his feet, while he leaned forward and carefully examined it. At last it rose vertically to about the level of his head, so he threw himself back in his chair and continued to watch it. It then became slightly elongated, and moved obliquely towards a hole pierced to the chimney about a yard above the mantelpiece. This hole had been made for the chimney of a stove which was used in winter. "But," as the tailor said, "the globe could not see the hole, for paper had been pasted over it." The globe went straight for the hole, tore off the paper, and went up the chimney. After the lapse of time which, at the rate at which he had seen it moving, it would have required to get to the 
top of the chimney, a terrific explosion was heard, and a great deal of damage was done to the chimney and the roofs around it.

The next is even more striking: In June, 1849 , in the evening of one of the days when cholera was raging most formidably in Paris, the heat was suffocating, the sky appeared calm, but summer lightning was visible on all sides. Madame Espert saw from her window something like a large red globe, exactly resembling the moon when it is seen through mist. It was descending slowly towards a tree. She at first thought it was a balloon, but its colour undeceived her; and while she was trying to make out what it was she saw the lower part of it take fire (" $7 \varepsilon v i$ is le feu prendre au bas de ce globe"), while it was still some yards above the tree. The flames were like those of paper burning slowly, with sparks and jets of fire: When the opening became twice or thrice the size of one's hand, a sudden and terrific explosion took place. The infernal machine was torn to pieces, and a dozen flashes of zig-zag lightning escaped from it in all directions. The débris of the globe burned with a brilliant white light and revolved like a catherine-whecl. The whole affair lasted for at least a minute. A hole was bored in the wall of a house, three men were knocked down in the street, and a governess was wounded in a neighbouring school, besides a good deal of other damage.

I have never seen one myself, but I have received accounts of morc than one of them from competent and thoroughly credible eye-witnesses. In particular on a stormy afternoon in November, 1868, when the sky was densely clouded ovcr, and the air in a highly electrical state, there was heard in Edinburgh one solitary short, but very loud, clap of thunder. There can be no doubt whatever that this was duc to the explosion of a fire-ball, which was seen by many spectators, in different parts of the town, to descend towards the Calton Hill, and to burst whilst still about a hundred feet or so above the ground. The various accounts tallied in most particulars, and especially in the very close agreement of the positions assigned to the ball by spectators vicwing it from different sides, and in the intervals which were observed to elapse between the explosion and the arrival of the sound.

The remaining phenomena of a thunderstorm are chiefly the copious fall of rain and of hail, and the almost invariable lowering of the barometer. These are closely connected with one another, as we shall presently see.

\section{(To be continued.)}

\section{THE BRITISH ASSOCIATION}

$\mathrm{W}$

$\mathrm{E}$ had but just time before going to press last week to indicate the general arrangements made for the reception at Swansea of the British Association. We have now to chronicle the events of the meeting which, although small, has not been destitute of many points of interest. The actual number of members and associates in attendance has been smaller than is shown by the returns for many previous years. This is probably accounted for by the geographical isolation of Swansea and the smallness of its population ; but there are doubtless other collateral causes-such, for example, as the coincidence of the meeting of the Iron and Steel Institute at Düsseldorf-which have contributed to discourage a large attendance.

At the General Committee meeting on August 25 the Report of the Council for the year I879-80 was presented.

The Council having been requested by the General Committee at Sheffield to take such further action as regards the correspondence with the Treasury about the Natural History Collections as they should think desirable in the interests of science, prepared and sent to the Secretary of the Treasury, in reply to his letter of July 22, I 879, the following letter :-
"British Association for the Advancement of Suience, "22, Albemarle Street, London, W., June 8, 1880

"SIR,-The letter of the Council of this Association, of March 25, 1879 , respecting the administration of the Natural History Collections, and your reply thereto of July 22, have been laid before the British Association, at the meeting held at Sheffield in August last, when the subject was again referred to the Council.

"On the part of the Council I am now requested to inform you that they learn with satisfaction that the action of Her Majesty's Government, in passing the British Museum Act of 1878 , does not prejudice the question of the future administration of the Natural History Collections at South Kensington, but that the subject is still under the consideration of the Lords Commissioners of Her Majesty's Treasury.

"Under these circumstances the Council of the Association must again express their hope that, when the period arrives, as it must shortly do, for the settlement of the question, the recommendations of the Royal Commission on Science will have their full weight and importance accorded to them.

"If, however, the Lords Commissioners of Her Majesty's Treasury are prepared, as they would seem to indicate, to constitute a Special Standing Committee, or Sub-Committee, of the Trustees of the British Museum, for the management of the Natural History Collections, the Council of the Association are of opinion that such a form of government, though not the form suggested by the Royal Commission on Science, might possibly be so organised as to be satisfactory both to the public and to men of science.

"Trusting that the Lords Commissioners will do the Council the favour of considering these observations on a subject which keenly interests many members of the British Association, "I have the honour to be, sir, "Your obedient servant, "G. J. Allman, "President of the British Association for the Advancement of Science.

"SIR R. R. W. LiNGEN, K.C.B., \&c., \&c."

The receipt of this letter has been acknowledged.

The Council have elected Prof. Cornu, of Paris, and Prof. Boltzmann, of Vienna, Corresponding Members since the Sheffield meeting.

The president's address was very well received; and suffered nothing from the extempore style adopted by Prof. Ramsay, who held his audience to the end. The presidential addresses of the sections were of an unusually high order, and happily no hitch occurred this year to necessitate the delay of any of them beyond the day and hour fixed for their delivery. We reprinted some of them last week, and others will be found in our columns to-day. of papers in the different sections there has not been, perhaps, as plentiful a supply as in other years, Section $G$ exhibiting a decided lack. There has been certainly a less amount of illustration by diagrams and experiments in the Section meetings than is usual, though several papers in Section A were accompanied by the exhibition of new forms of apparatus. The Neanderthal skull exhibited by Prof. Schaffhausen of Bonn in Section D drew an inquisitive crowd of admirers. The excursions to the local centres of industry - the Dowlais Works, the Landore Steel Works, and the various copper and tin works thrown open by the courtesy of their proprietors-were deservedly popular. Some of these specially invited the notice of Section $G$, which on the very first day of meeting adjourned for a visit to Dowlais. The promoters of the new East Dock have not omitted to seek for possible shareholders in the members of the Association.

The Saturday excursions to Milford, Gower, St. 